\title{
NOTES ON THE SUBTRIBE CHLORAEINAE (ORCHIDACEAE)
}

\author{
DARIUSZ L. SZlachetKo, Piotr TuKaŁŁo \\ Department of Plant Taxonomy and Nature Conservation, Gdansk University \\ Al. Legionów 9, 80-441 Gdańsk, Poland \\ e-mail: biodarek@univ.gda.pl
}

(Received: January 10, 2007. Accepted: February 27, 2007)

\begin{abstract}
The current and past taxonomic status of Chloraeinae is presented; concepts of subtribe origin are also discussed. Two genera are described as new to science: Chileorchis Szlach., gen. nov., Correorchis Szlach., gen. nov. and six new combinations at the species level are validated. Two other genera, Bieneria Rchb.f. and Ulantha Hook., are reinstated. Additionally, a key to genera of Chloraeinae is provided.
\end{abstract}

KEY WORDS: Chloraeinae, Orchidaceae, nomenclature, taxonomy.

\section{INTRODUCTION}

In Schlechter's (1926) system, Chloraeinae embraced three genera, Asarca $(=$ Gavilea $)$ Lindl., Bipinnula Comm. ex A.Juss. and Chloraea Lindl. The South American Codonorchis Lindl. was included in Caladeniinae, while Megastylis Schltr. formed a monotypic subtribe. All these genera were placed with Chloraeinae by Dressler $(1981,1993)$ as well as by Burns-Balogh and Funk (1986). In view of the presence of clustered roots and basal leaf rosettes, Brieger (1974-1975) proposed a different concept of Chloraeinae, placing it in the tribe Spirantheae, together with Cranichidinae and Spiranthinae. He divided Chloraeinae into two "Gattungsreihen", Aviscidia (Bipinnula Comm. ex Juss., Chloraea, Gavilea Poeppig, Geoblasta Barb.Rodr.) and Viscidifera (Megastylis, Pachyplectron Schltr., Rimacola Rupp). On the other hand, Codonorchis, ranked as a monotypic subtribe, was placed among Diurideae.

Thus the questions arises whether conditions exist for the singling out of Chloraeinae and Caladeniinae and on what criteria. Chloraeinae are usually distinguished from Caladeniinae by their geographical distribution, the lack of root-stem tuberoids and viscidium. Caladeniinae contains mainly Australian genera, whereas Chloraeinae - South American and eventually New Caledonian ones. We have noted viscidia in all the species of Chloraeinae studied (Szlachetko and Rutkowski 2000). Codonorchis and Geoblasta have root-stem tuberoids similar to those of Caladenia R.Br. Ackerman and Williams (1981) stated that the pollen morphology and organization of the Chloraeinae is most similar to the Caladeniinae.

Chloraeinae, as proposed here, appear to be polymorphic if their vegetative parts are considered, and relatively con- stant in their flower and gynostemium structure. Based on the structure of storage organs it can be divided into two subgroups:

- fleshy tubers - Australian Burnettia Lindl., Lyperanthus R.Br., Pyrorchis Jones, Molloy and Clements and $\mathrm{Wa}$ ireia Jones, Molloy and Clements, and South American Codonorchis and Geoblasta;

- clustered roots - New Caledonian Megastylis, Australian Rimacola, and South American Bipinnula, Chloraea, Gavilea and Jouyella Szlach.

The other line of division of this group can be the number of leaves per shoot:

- single-leafed plants - Australian Burnettia, Lyperanthus, Pyrorchis, Rimacola and Waireia;

- multiple-leaved plants - New Caledonian Megastylis and South American Bipinnula, Chloraea, Gavilea, Geoblasta and Jouyella.

In our opinion, attaching excessively great importance to the geographical distribution of the genera in question may be misleading, since no correlation with morphological characters can be observed. The loss of root-stem tuberoids may be a secondary state (cf. Orchidinae) and be dependent upon the biotopic conditions, similarly as the seed types (cf. Dressler 1993).

According to results of the molecular studies based on plastid genome, Pridgeon et al. (2001) and Kores et al. (2001) divided Chloraeinae s.l. into Chloraeinae s.str., Megastylidinae and Codonorchideae. The reason for this standpoint was given by Kores et al. (2001) on the combined $m a t \mathrm{~K}$ and $t r n \mathrm{~L}-\mathrm{F}$ tree, showing unequivocal separation of Chloraeinae s.str. from Megastylidinae. The former group together with Pterostylideae and Cranichideae was placed in a branch forming the spiranthid lineage while the 


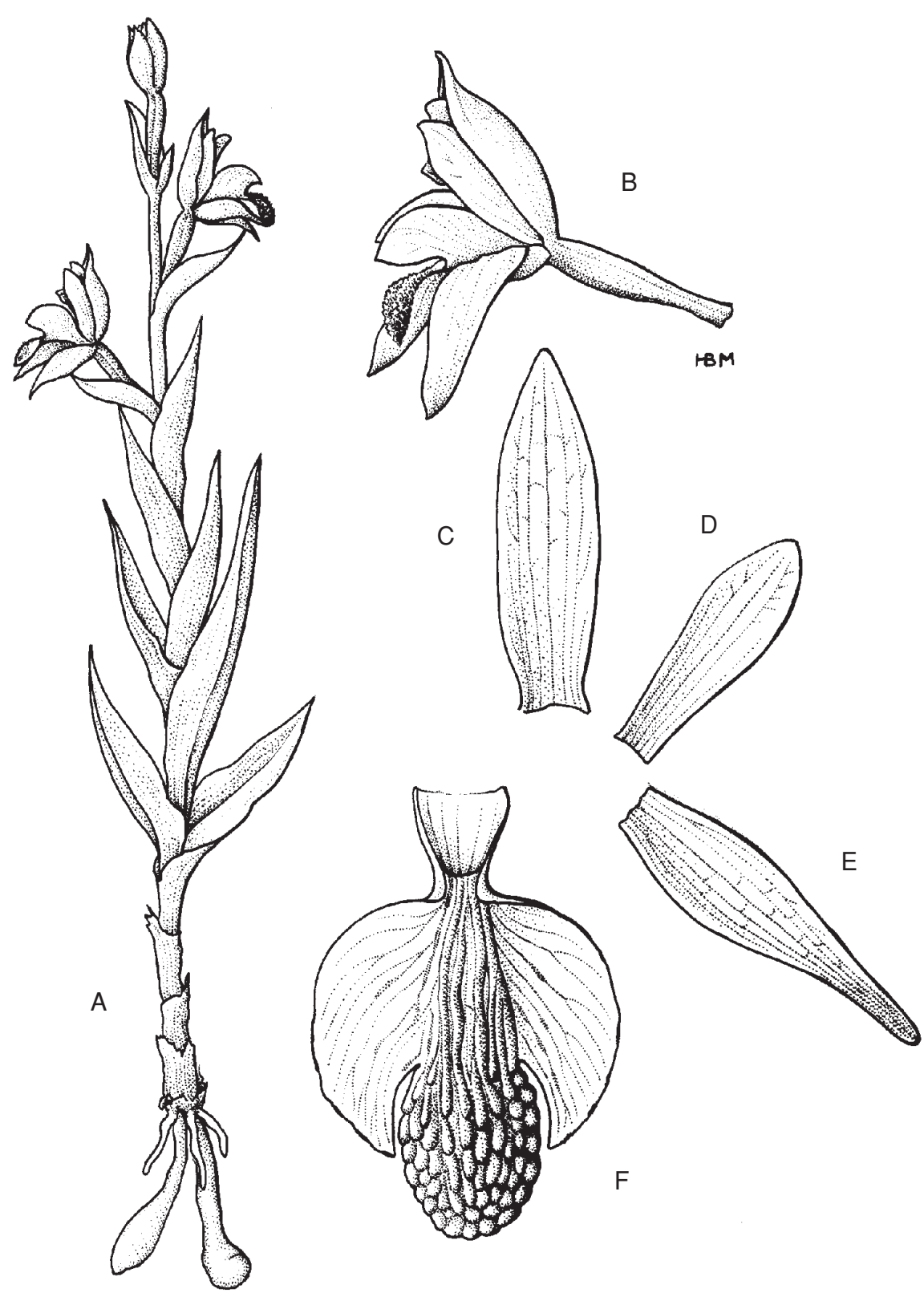

Fig. 1. Chileorchis disoides: A - plant with inflorescence; B - flower, side view; C - dorsal sepal; D - petal; E - lateral sepal; F - lip (redrawn from Correa 1969). latter one was numbered among the diurid lineage. It is also worth noting that Megastylis followed the same separation scheme between the spiranthid and the diurid lineages.

There are at least two possibilities for explaining such a high diversity of Chloraeinae s.l. The whole group descended from a common ancestor similar to the contemporary Chloraea, which could penetrate New Caledonia, giving arise to Megastylis. Afterwards both lines evolved independently losing clustered roots for the benefit of tubers. The excellent representation of that process in an American line is a sequence of the following genera:

- Chloraea with monomorphic roots;

- Jouyella with dimorphic roots, part of which is clearly tuberously thickened and the other ones narrow and thin;

- Geoblasta with a single, narrow, cylindrical tuber.

Additionally, in the Australian line, a distinct tendency to reduction of leaves number was marked. It might be possible that ancestor of Chlorainae was approximately a contemporary Rimacola. The New World was settled twice the remnant of the first migrants could be Codonorchis, molecularly different from the other Geoblasteae but mor- phologically similar to the rest of Chloraeinae. From the second wave of migrants, of what an indirect grade could be Megastylis, descended the other South American Chloraeinae. A scenario of further evolutionary changes in both continents could be similar to this one shown above. That hypothesis seems to be the most feasible in our opinion. The third possible explanation of such situation is the independent origin of Megastylidinae and Chlorainae s.str., suggested by results of molecular studies. This concept is not much credible in our opinion since it might assume a considerable convergence to the representatives of both groups in respect of the gynostemium and flower structure, including the appearance of similar structures on a lip. Those characters might be the results of convergence.

No matter which of the above hypotheses is true, the presented problem is intellectually exciting and worth to work out. In view of the above, it is better to keep Chloraeinae in their wide concept, instead of splitting it between various taxa, which are morphologically indefinable. 

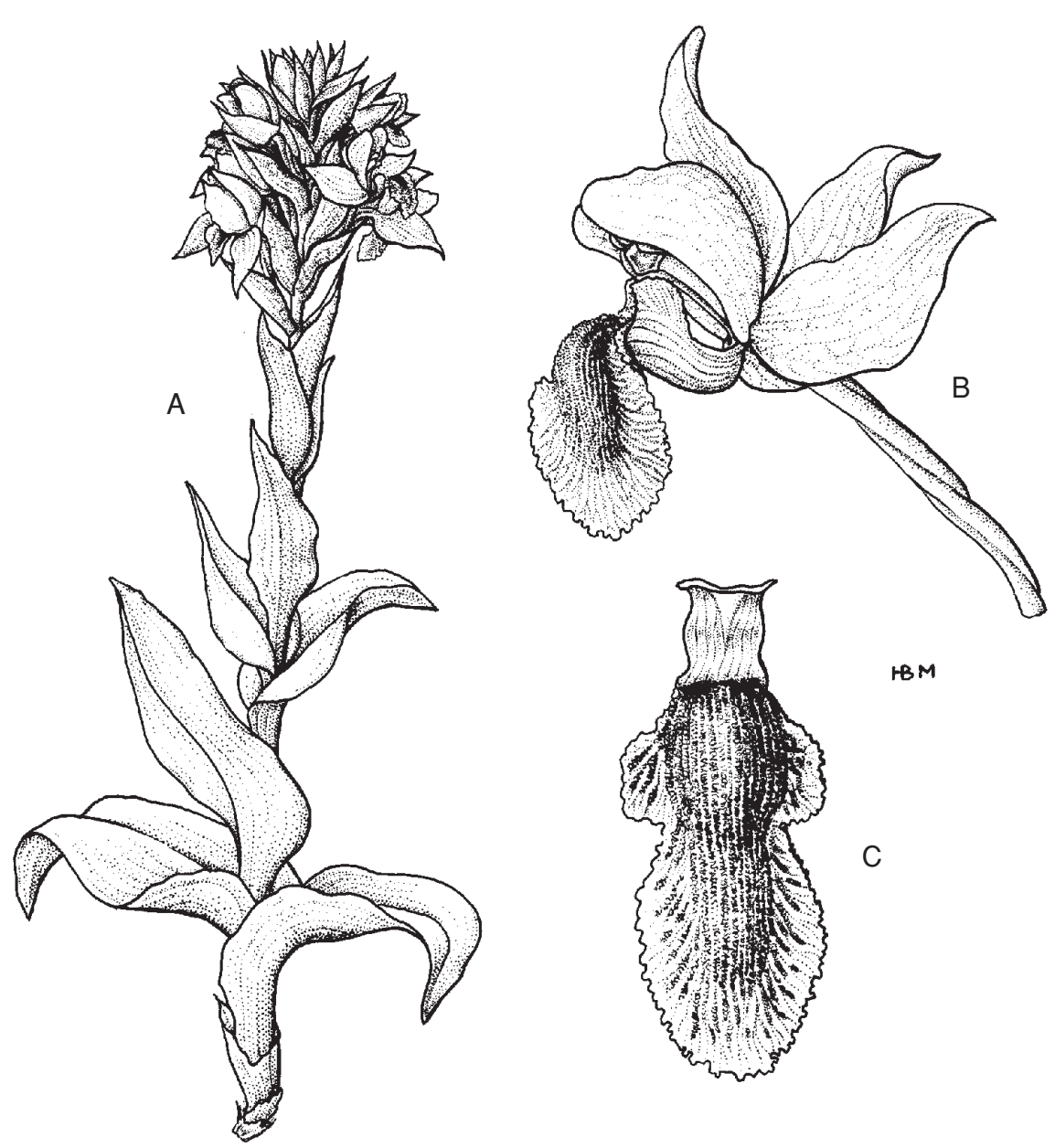

Fig. 2. Bienneria densipapillosa: A - plant with inflorescence; B - flower, side view; C - lip, front view (redrawn from Correa 1969).

\section{Subtribe Chloraeinae Rchb.f.}

Roots clustered, fleshy, root-stem tuberoids present in some genera. Stem glabrous (cf. Achlydosa!). Column foot usually obscure. Gynostemium somewhat swollen apically. Staminodes narrowly winged of the gynostemium, or forming a mitra-like structure (Gavilea). Apices of the staminodes reduced. Viscidium cellular, prominent.

Ten of 17 genera included in Chloraeinae are known from South America, the others from Australia and New Caledonia. In our opinion the most valuable as diagnostic features on generic levels are storage organs morphology, leaves morphology, lip and perianth segments structure and gynostemium architecture. Based on the combination of aforementioned features we tried to characterize each genus. In result all taxa are polythethic, what form them natural.

\section{KEY TO THE GENERA OF CHLORAEINAE}

1a. Exclusively Australian genera...................................... 2

1b. New World genera ................................................... 8

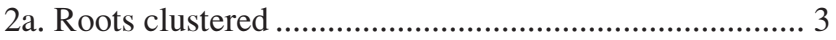

2b. Root-stem tuberoids present...................................... 5

3a. Plants over $50 \mathrm{~cm}$ tall .............................................. 4

3b. Plants up to $25 \mathrm{~cm}$ tall ................................. Rimacola

4a. Plant glabrous. Lip with papillate calli ......... Megastylis

4b. Inflorescence and perianth glandular. Lip with no papillate calli on th upper surface ............ Achlydosa

5a. Leaves reduced to fleshy, sheathing scales .... Burnettia 5 b. Leaf fully developed ..... 6a. Lip entire, clawed Waireia

6b. Lip 3-lobed, sessile. 7

7a. Leaf protrate with abaxial surface glabrous ... Pyrorchis 7b. Leaf erect with abaxial surface minutely papillate. Lyperanthus

8a. Lateral sepals with club-like, fimbriate or hairy thickennings in the apical half

8b. Lateral sepals with no such thickenings 9

9a. Plants leafless or with withering lea flants leafless or with withering leaf at flowering. Inflorescence single-flowered. Lip strongly thickened and insectiform

Bipinnula

9b. Plants leafy at flowering. Inflorescence many (10-20) flowered. Lip thin, delicate, entire, usually ovate to cordate. Jouyella

10a. Column part conspicuously winged, so rostellum, stigma and partly anther are hidden Gavilaea

10b. Column part obscurely winged 11

11a. Stigmatic surface oblong, longer than half of the entire gynostemium length.

Codonorchis

11b. Stigma elliptic or oval, distinctly shorter than half of the gynostemium. 12

12a. Plants with tubers. Lip entirely covered with fleshy, cylindrical calli.

Geoblasta

12b. Plants with clustered roots. Lip covered by various kind of appendages but no cylindrical calli. 13

13a. Lip thin, membraneous, with few to several rows of clavate calli or lamina....

Chloraea

13b. Lip at least partially thickened, verrucose or sulcate-rugose 


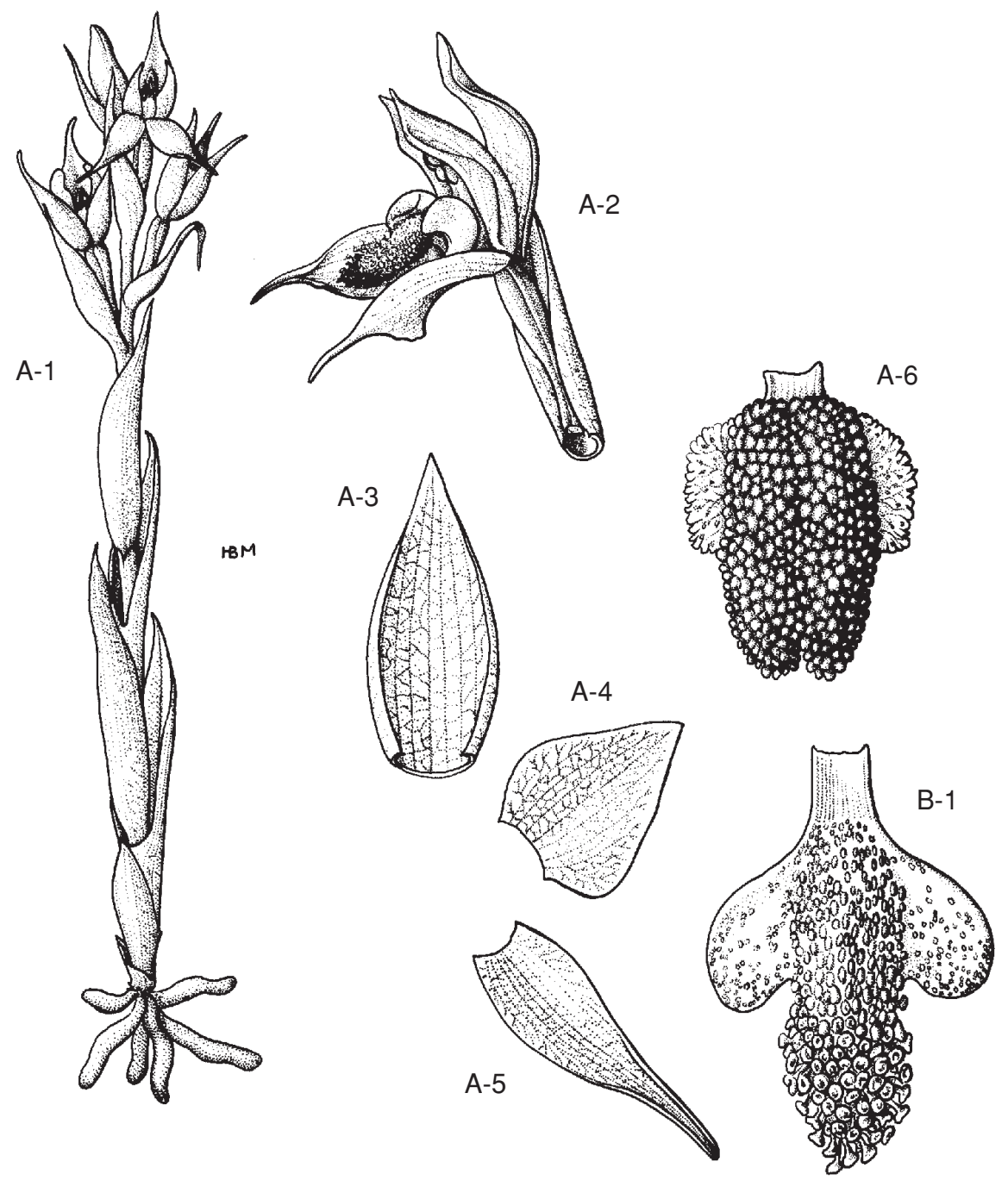

Fig. 3. A - Ulantha grandiflora; A-1 - plant with inflorescence; A-2 - flower, side view; A-3 - dorsal sepal; A-4 - petal; A-5 - lateral sepal; A-6 - lip, front view; B - Ulantha apinnula; B-1 - lip, front view (redrawn from Correa 1969). 14a. Lip pulvinate in the center or at the base, sulcate-rugose.. Bieneria

14b. Lip at least partially verrucose on the upper surface

15a. Lip thickened and verrucose from the base to the apex, except lateral lobes. Petals very wide, widest below the middle..... Ulantha

15b. Apical half of the lip fleshy, thickened, verrucose. Petals narrow, widest above the middle

16a. Lip entire, margins covered by clavate appendages in the lower half.

Correorchis

16b. Lip 3-lobed, margins entire Chileorchis

\section{CHILEORCHIS Szlach., gen. nov.}

Genus hoc a habitu et structura gynostemii generi Chloreae appropinquat sed labello marginibus integris, unguo insidens, trilobato, basi tenui lamellis carnosis tecto et lobo centrali crasso, carnoso verrucosove. Petala angustata in parte apicali latiora.

GENERITYPE: Chileorchis disoides (Lindl.) Szlach. (=Chloraea disoides Lindl.).

ETYMOLOGY: In reference to the known distribution of the only species of the genus.

Roots clustered, fleshy, fusiform. Leaves cauline, decreasing in size upwards. Inflorescence few-flowered. Flowers medium-sized, resupinate. Tepals dissimilar, membranaceous, narrow. Lip unguiculate, 3-lobed, the basal part thin, membraneous, covered by fleshy lamellae, the median lobe fleshy towards the apex, verrucose. Gynostemium elongate, slender. Column part prominent, obscurely winged. Column foot rudimentary, Anther base near the stigma apex. Anther erect, immovable, ovoid-conical. Pollinia 4, oblong, powdery. Stigma subsessile, obovate to elliptic. Rostellum shelf-like, truncate (Fig. 1).

A monospecific genus from Chile.

Chileorchis disoides (Lind1.) Szlach., comb. nov

BASIONYM: Chloraea disoides Lindl. in Brandes, Quart. J. Sci., Lit. Art. 1: 147. 1827.

\section{BIENERIA Rchb.f.}

GENERITYPE: Bieneria boliviana Rchb.f., Bot. Zeitung (Berlin). 11: 3, t. 1. 1853

Roots clustered, fleshy, fusiform. Leaves cauline, gradually decreasing in size upwards. Inflorescence few - to many-flowered. Flowers medium-sized, conspicuous, resupinate. Tepals dissimilar, membranaous, large, wide. Lip long unguiculate, 3-lobed or entire, thin, membraneous, the middle part pulvinate, sulcate-rugose, fleshy, margins membraneous, crenulate, undulate. Gynostemium elongate, slender. Column part prominent, obscurely winged, wider near the stigma. Column foot rudimentary, Anther base near the stigma apex. Anther erect, immovable, ovoid, attenuate towards the apex. Pollinia 4, oblong, powdery. Stigma 


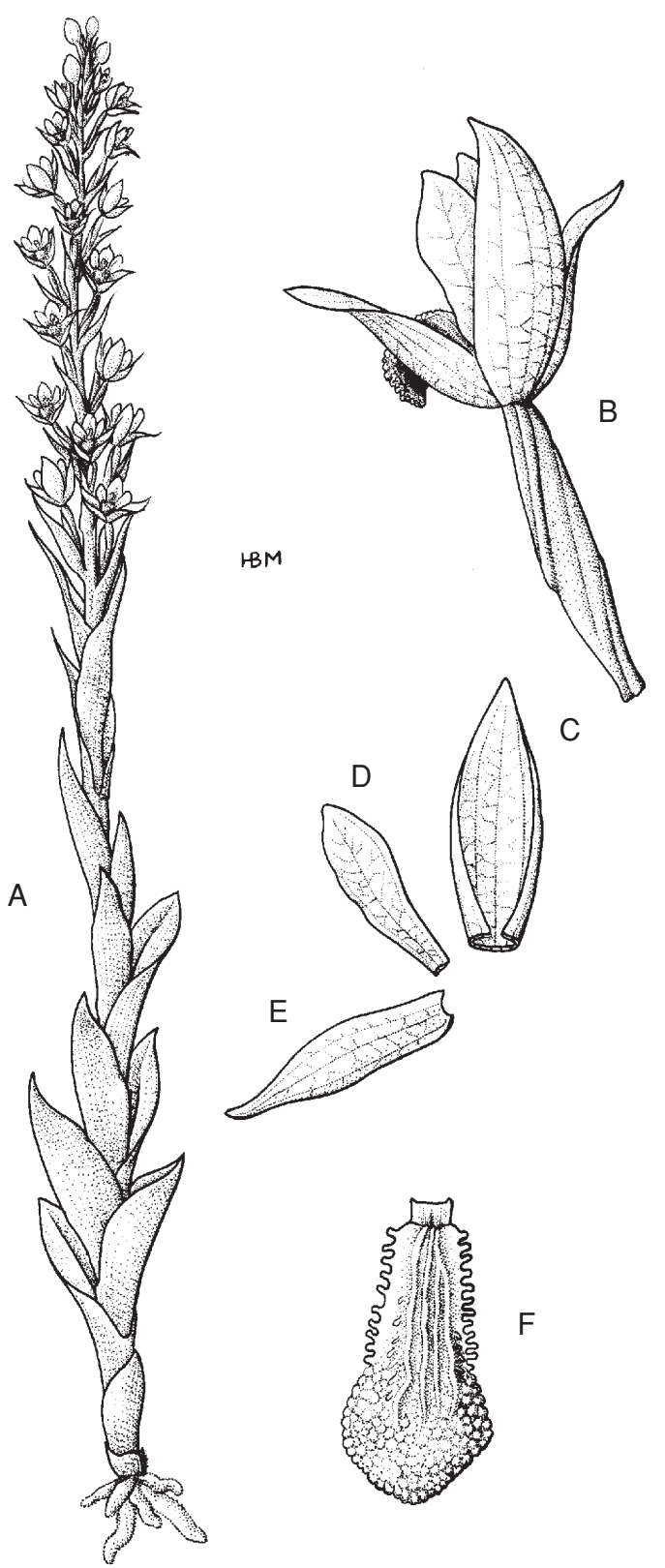

Fig. 4. Correorchis cylindrostachya: A - plant with inflorescence; B - flower, side view; C - dorsal sepal, D - petal; E - lateral sepal; F - lip, front view (redrawn from Correa 1969).

subsessile, obovate to elliptic. Rostellum shelf-like, truncate (Fig. 2).

A genus of three species known from Peruvian and Bolivian Andes.

Bieneria boliviana Rchb.f., Bot. Zeitung (Berlin). 11: 3, t. 1. 1853.

SYNONYM: Chloraea boliviana (Rchb.f.) Kraenzl., Syst. Bot. Jahrb. 37: 397. 1906.

Bieneria densipapillosa (C.Schweinf.) Szlach., comb. nov. BAsionym: Chloraea densipapillosa C.Schweinf., Bot. Mus. Leafl., Harvard Univ. 9: 55. 1941.

Bieneria multilineolata (C.Schweinf.) Szlach., comb. nov. BASIONYM: Chloraea multilineolata C.Schweinf., Bot. Mus. Leafl., Harvard Univ. 9: 57. 1941.
ULANTHA Hook.

GENERITYPE: Ulantha grandiflora Hook. in Curtis, Bot. Mag.: 57, t. 2990 and 2956. 1830.

Roots clustered, fleshy, fusiform. Leaves cauline, decreasing in size gradually upwards. Inflorescence few-flowered. Flowers large, conspicuous, resupinate. Tepals dissimilar. Lateral sepals canaliculate, attenuate. Lip unguiculate, 3-lobed, fleshy, verrucose from base to the apex; lateral lobes thin, delicate. Gynostemium elongate, slender. Column part prominent, obscurely winged. Column foot rudimentary. Anther base near the stigma apex. Anther erect, immovable, ovoid. Pollinia 4, oblong, powdery. Stigma subsessile, obovate to elliptic. Rostellum shelf-like, truncate (Fig. 3).

A genus of two species known from Chile.

Ulantha apinnula (Gosewijn) Szlach., comb. nov.

BASIONYM: Bipinnula apinnula Gosewijn, Gayana Bot. 50 (1): 12.1993.

Ulantha grandiflora (Poepp.) Szlach., comb. nov. BASIONYM: Chloraea grandiflora Poepp., Frag. Syn. pl. Phan.: 14. 1833.

\section{CORREORCHIS Szlach., gen. nov.}

Genus hoc a habitu et structura gynostemii generi Chloreae simile sed labello indiviso, unguo insidens, basi lamellis et a margines appendicibus carnosis tecto, in parte apicali rhombeo, carnoso verrucosove.

GENERITYPE: Correorchis cylindrostachya (Poepp.) Szlach. (=Chloraea cylindrostachya Poepp.).

ETYMOLOGY: Dedicated to Dr. Maevia Correa, an author of the monograph of the genus Chloraea.

Roots clustered, fleshy, fusiform. Leaves cauline, gradually decreasing in size upwards. Inflorescence few - to many-flowered. Flowers medium-sized, resupinate. Tepals dissimilar, membraneous. Petals narrow. Lip unguiculate, entire, the basal half oblong, thin and membraneous, covered by lamellae on disc and by clavate appendages along margins, the apical part rhomboid, fleshy, verrucose. Gynostemium elongate, slender. Column part prominent, obscurely winged. Column foot rudimentary. Anther base near the stigma apex. Anther erect, immovable, ovoid-conical, attenuate towards the apex. Pollinia 4, oblong, powdery. Stigma subsessile, obovate to elliptic. Rostellum shelflike, truncate (Fig. 4).

A genus of one species native to Chile and Argentina.

Correorchis cylindrostachya (Poepp.) Szlach., comb. nov. BAsIOnYM: Chloraea cylindrostachya Poepp., Frag. Syn. Pl. Phan.: 15. 1833.

\section{ACKNOWLEDGMENTS}

We are grateful to Dr. Hanna B. Margońska for preparing drawings for this publications.

\section{LITERATURE CITED}

ACKERMAN J.D., WILLIAMS N.H. 1981. Pollen Morphology of the Chloraeinae (Orchidaceae: Diuridae) and Related Subtribes. Am. J. Bot. 68: 1392-1402. 
BRIEGER F.G. 1974-1975. 3. Unterfamilie: Neottioideae. In: F.G. Brieger, R. Maatsch, K. Senghas (eds), Die Orchideen. R. Shlechter. Paul Parey Verlag. Berlin-Hamburg. pp. 284-358.

BURNS-BALOGH P., FUNK V.A. 1986. A phylogenetic analysis of the Orchidaceae. Smiths. Contr. Bot. 61: 1-79.

CORREA M.N. 1969. Chloraea, genero Sudamericano de Orchidaceae. Darwiniana 15: 374-500.

DRESSLER R.L. 1981. The Orchids: natural history and classification. Harvard University Press, Cambridge.

DRESSLER R.L. 1993. Phylogeny and classification of the orchid family. Dioscoroides Press, Portland.

KORES P.J., CAMERON K.M., CHASE M.W. 2001. A phylogenetic analysis of Diurideae (Orchidaceae) based on plastid DNA sequence data. Am. J. Bot. 88: 1903-1914.
PRIDGEON A.M. 2001 Anatomy of Megastylidinae. In: A.M. Pridgeon, P.J. Cribb, M.W. Chase, F.N. Rasmussen (eds), Genera Orchidacearum, vol. 2, Orchidoideae part 1, 155-156. Oxford University Press, Oxford, UK.

SCHLECHTER R. 1926. Das System der Orchidaceen. Notizbl. Bot. Gart. Mus, Berlin-Dahlem 9, 563-591.

SZLACHETKO D.L., RUTKOWSKI P. 2000. Gynostemia Orchidalium - Vol. 1 Apostasiaceae, Cypripediaceae, Orchidaceae (Thelymitroideae-Vanilloideae). Acta Bot. Fennica 169: 1-380. 